\title{
EGF activates an inducible survival response via the RAS-> Erk-1/2 pathway to counteract interferon- $\alpha-$ mediated apoptosis in epidermoid cancer cells
}

\author{
M Caraglia ${ }^{1}$, P Tagliaferri ${ }^{2}$, M Marra ${ }^{1}$, G Giuberti ${ }^{1}$, A Budillon ${ }^{3}$, \\ E Di Gennaro ${ }^{3}$, S Pepe ${ }^{4}$, G Vitale $^{4}$, S Improta ${ }^{1}$, P Tassone ${ }^{2}$, \\ $S$ Venuta ${ }^{2}, A R$ Bianco ${ }^{4}$ and $A$ Abbruzzese ${ }^{*, 1}$ \\ 1 Dipartimento di Biochimica e Biofisica, Seconda Universitá di Napoli, \\ ViaCostantinopoli, 16 80138, Naples, Italy \\ 2 Dipartimento di Medicina Sperimentale, Università 'Magna Grecia' di \\ Catanzaro, Italy \\ 3 Istituto Nazionale dei Tumori 'G Pascale', Naples, Italy \\ ${ }^{4}$ Dipartimento di Endocrinologia ed Oncologia Molecolare e Clinica, Università \\ 'Federico II' di Napoli, Naples, Italy \\ * Corresponding author: A Abbruzzese, Dipartimento di Biochimica e Biofisica, \\ Seconda Universitá di Napoli, Via Costantinopoli, 16 80138, Naples, Italy
}

Received 23.5.02; revised 24.7.02; accepted 28.8.02

Edited by G. Ciliberto

\begin{abstract}
The mechanisms of tumor cell resistance to interferon- $\alpha$ (IFN $\alpha)$ are at present mostly unsolved. We have previously demonstrated that IFN $\alpha$ induces apoptosis on epidermoid cancer cells and EGF antagonizes this effect. We have also found that IFN $\alpha$-induced apoptosis depends upon activation of the $\mathrm{NH}_{2}$-terminal Jun kinase-1 (Jnk-1) and $\mathrm{p}^{38}$ mitogenactivated protein kinase, and that these effects are also antagonized by EGF. At the same time, IFN $\alpha$ increases the expression and function of the epidermal growth factor receptor (EGF-R). Here we report that the apoptosis induced by IFN $\alpha$ occurs together with activation of caspases 3,6 and 8 and that EGF also antagonizes this effect. On the basis of these results, we have hypothesized that the increased EGF-R expression and function could represent an inducible survival response that might protect tumor cells from apoptosis caused by IFN $\alpha$ via extracellular signal regulated kinase 1 and 2 (Erk-1/2) cascades. We have found an increased activity of Ras and Raf-1 in IFN $\alpha$-treated cells. Moreover, IFN $\alpha$ induces a $50 \%$ increase of the phosphorylated isoforms and enzymatic activity of Erk-1/2. We have also demonstrated that the inhibition of Ras activity induced by the transfection of the dominant negative Ras plasmid RASN17 and the inhibition of Mek-1 with PD098059 strongly potentiates the apoptosis induced by IFN $\alpha$. Moreover, the selective inhibition of this pathway abrogates the counteracting effect of EGF on the IFN $\alpha$-induced apoptosis. All these findings suggest that epidermoid tumor cells counteract the IFN $\alpha$-induced apoptosis through a survival pathway that involves the hyperactivation of the EGF-dependent Ras->Erk signalling. The selective targeting of this pathway appears to be a promising approach in order to enhance the antitumor activity of IFN $\alpha$.
\end{abstract}

\author{
Cell Death and Differentiation (2003) 10, 218-229. doi:10.1038/ \\ sj.cdd. 4401131
}

Keywords: Epidermal growth factor receptor; Dominant negative Ras; Mek-1 inhibitor; Caspases; New anticancer strategies

Abbreviations: IFN $\alpha$, Interferon- $\alpha$; JNK-, Jun kinase-1; EGF-R, Epidermal growth factor receptor; MAPK, Mitogen-activated protein kinase

\section{Introduction}

Interferon- $\alpha$ (IFN $\alpha)$ is a biological agent widely used in the therapy of several neoplasms such as myeloma, renal cell carcinoma, epidermoid cervical and head and neck tumors and melanoma. ${ }^{1-5}$ IFN $\alpha$, the first cytokine to be produced by recombinant DNA technology, has emerged as an important regulator of cancer cell growth and differentiation, affecting cellular communication and signal transduction pathways, and is also produced during the immunological control of tumor growth. ${ }^{5}$ However, inconsistent data have been obtained regarding the clinical effectiveness of IFN $\alpha$ in the therapy of solid tumors. In fact, the benefit of IFN $\alpha$ treatment is limited to some neoplasms while others are completely or partially resistant. The mechanisms of tumor resistance to IFN $\alpha$ have been studied in vitro. The alteration of JAK-STAT components of the IFN $\alpha$-induced signalling can be indeed a mechanism of resistance to IFN. In fact, it has been shown that melanoma cell lines refractory to the antiproliferative effects of IFNs are deficient in STATs and that the expression of STATs can be restored by in vitro gene therapy. ${ }^{6}$ More germane to clinical practice is the possibility that IFN treatment could be improved by the concomitant administration of agents known to enhance JAK-STAT responses; the use of retinoids in combination with IFN $\alpha$ in cancer therapy is a salient example. . $^{7,8}$

The way in which tumor cell growth is suppressed by IFN $\alpha$ is not well known. A possibility is that cancer cells undergo apoptosis after exposure to the cytokine. In fact, it is reported that IFN $\alpha$ induces apoptosis in human squamous cancer, 9,10 glioma ${ }^{11}$ and virus-infected cells. ${ }^{12}$ Therefore, it is likely that this cytokine acts, at least in part, through the triggering of programmed cell death.

On the other hand, EGF is able to protect eukaryotic cells from the onset of apoptosis. ${ }^{13-16}$ EGF acts through the binding to its specific receptor, EGF-R a transmemembrane protein with a cytoplasmic tyrosine kinase domain. ${ }^{17,18}$ The phosphorylation of the intracytoplasmic tail allows the interaction of EGF-R with cytoplasmic factors that can induce Ras activation and the subsequent stimulation of the mitogenactivated protein kinase (MAPK) cascade composed of three 
intracellular protein kinases (MKKK, MKK and MAPK), which are activated successively by phosphorylation events. ${ }^{17,18}$ Raf-1, stimulated after steric interaction with Ras, phosphorylates and activates an MKK whose main component is Mek1. Mek-1 phosphorylates the MAPKs extracellular signal regulated kinase 1 and 2 (Erk-1/2) that translocate to the nucleus and phosphorylate gene transactivators, such as the serum response factor-1, that are involved in the regulation of cell proliferation. ${ }^{17,18}$ Moreover, it has been recently reported that Erks mediate a strong antiapoptotic effect. ${ }^{19,20}$ For instance, Erk plays an important role in protecting cardiac myocytes from apoptotic death following oxidative stress. ${ }^{21}$ Protection of PC12 cell death by $\mathrm{N}$-acetylcysteine requires Erk activation ${ }^{20}$ that is, moreover, involved in the phorbol myristate acetate-mediated inhibition of drug-induced apoptosis in tumor cells. ${ }^{22}$

We have reported that IFN $\alpha$ increases the functional expression of the epidermal growth factor receptor (EGF-R) at the surface of human epidermoid carcinoma cells. ${ }^{23,24}$ Moreover, we have shown that IFN $\alpha$ induces apoptosis in these cells through the triggering of a stress response that leads to the activation of $\mathrm{NH}_{2}$-terminal Jun kinase-1 (Jnk-1). ${ }^{10}$ EGF also antagonizes these effects. On the basis of these findings, we have hypothesized that increased EGF-R expression and function could be part of an inducible survival pathway, which is activated in the tumor cells by exposure to IFN $\alpha$. In this paper, we have investigated the molecular basis of the counteracting effects of IFN $\alpha$ and EGF on the apoptosis of human epidermoid cancer cells. Specifically, we have evaluated the involvement of the caspase cascade and of EGF-dependent signalling in the apoptotic and antiapoptotic events recorded in our experimental model. We have then studied the effects of IFN $\alpha$ and EGF on the activity of Ras, Raf- 1 and Erk-1/2. We have finally evaluated if the selective inhibition of Ras and Mek-1 could enhance apoptosis induced by IFN $\alpha$ in order to provide direct evidence on the antiapoptotic activity of this pathway in our experimental model and to identify novel molecular targets to enhance the antitumor effects of this cytokine.

\section{Results}

\section{Effects of IFN $\alpha$ and EGF on the apoptosis of human epidermoid cancer cells}

We have found that IFN $\alpha$ (48 $1000 \mathrm{lU} / \mathrm{ml}$ ) induced apoptotic DNA fragmentation in the KB cell line and that the exposure of IFN $\alpha$-treated cells to $10 \mathrm{nM}$ EGF for $12 \mathrm{~h}$ antagonized this effect (Figure 1a). Before performing apoptosis detection assays, both attached and suspended cells were collected. In these experimental conditions, $30 \%$ of cells exposed to IFN $\alpha$ for $48 \mathrm{~h}$ were apoptotic while only about $8 \%$ of cells treated for $48 \mathrm{~h}$ with IFN $\alpha$ and exposed for $12 \mathrm{~h}$ to $10 \mathrm{nM}$ EGF underwent to apoptosis (Figure 1b). Interestingly, also the exposure to $10 \mathrm{nM}$ EGF alone for $12 \mathrm{~h}$ is able to induce apoptosis in $15 \%$ of the cell population (Figure 1a and b). Such an effect is not surprising since apoptosis and cell proliferation are coupled processes, and EGF can induce apoptosis in squamous cancer cells. In order to identify the molecular effectors of the apoptosis induced by IFN $\alpha$, we have evaluated the expression of p53 and c-myc and the activity of caspases in KB cells. We have found that apoptosis induced by either IFN $\alpha$ or EGF was paralleled by a significant increase of p53 and c-myc expression in KB cells, as evaluated with Western blot assay. The antagonism of EGF on apoptosis occurred together with the restoration of p53 and c-myc expression to basal levels (Figure 1C). We have thereafter studied the role of caspases in the modulation of apoptosis by IFN $\alpha$ and EGF in our experimental model. KB cells were treated with IFN $\alpha$ for 12 , 24,48 and $72 \mathrm{~h}$ and then the activity of caspases was evaluated with a fluorimetric protease assay. Caspases 6, 8 and 9 showed an activation peak after $24 \mathrm{~h}$ exposure to IFN $\alpha$ (Figure 2a). The activation peak of caspase 3 was instead found after $48 \mathrm{~h}$ exposure to the cytokine. Moreover, the exposure of KB cells to $10 \mathrm{nM}$ EGF for $12 \mathrm{~h}$ was always able to antagonize the caspase activation induced by IFN $\alpha$ both at $24 \mathrm{~h}$ and $48 \mathrm{~h}$ (Figure 2b-d). In fact, EGF completely abrogated caspases 6,8 and 9 and caspase 3 activities. EGF alone also induced a slight increase of caspase stimulation, but the extent of activation was far lesser than that recorded in IFN $\alpha$-treated cells. Therefore, in our experimental model the IFN $\alpha$-induced apoptosis is correlated with the activation of the caspase cascade, and EGF was able to antagonize both apoptotic death and caspase activation. Moreover, the apoptosis recorded in KB cells exposed to EGF alone did not appear to be induced by a caspase pathway similar to that recorded in IFN $\alpha$-treated cells.

\section{Effects of EGF and IFN $\alpha$ on Ras activity}

We have previously shown that IFN $\alpha$ induces growth inhibition paralleled by increased EGF-R expression and sensitivity to the growth-promoting effects of EGF in epidermoid cancer cells. $^{23,24}$ Therefore, we have investigated if the activity of the Ras-dependent MAPK pathway was increased in IFN $\alpha$ treated cells. This and all the following experiments were performed without serum starvation in order to set up more physiological experimental conditions. Moreover, EGF was added for short-term exposures in order to evaluate the responsiveness of each signalling component to its physiological ligand in untreated and IFN $\alpha$-treated KB cells. We have firstly studied the activity of Ras through the affinity precipitation of Ras with the minimal binding domain of Raf-1. We have found that the levels of activated Ras (linked to the minimal binding domain of Raf-1) were increased in IFN $\alpha$-treated cells. In fact, the activated Ras levels were about two-fold higher in IFN $\alpha$-treated cells than in control cells, and the stimulation of Ras activity by exposure to EGF for $10 \mathrm{~min}$ was further enhanced in IFN $\alpha$-treated cells reaching levels 3.5-fold higher than untreated controls (Figure 3). At longer times of exposure to EGF, Ras activity decreased either in EGF- or EGF/IFN $\alpha$ treated cells (Figure 3). Therefore, in IFN $\alpha$-treated KB cells, the increased activity of EGF-R signalling was indeed coupled to enhanced Ras activity and was further stimulated by the addition of exogenous EGF.

\section{Effects of IFN $\alpha$ and EGF on Raf-1 expression and activity}

We have evaluated the effect of IFN $\alpha$ and EGF on Raf-1 activity by a kinase assay using histone $\mathrm{H} 1$ as substrate of 


\section{a}

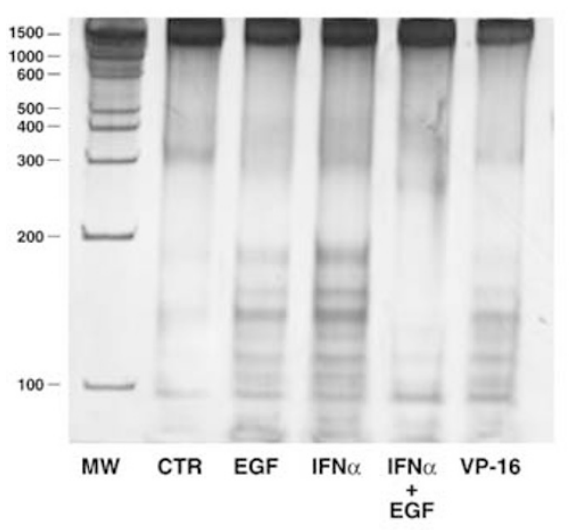

b

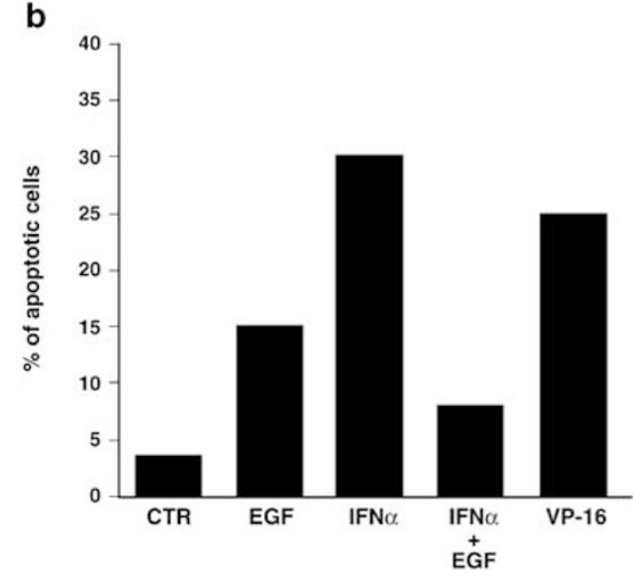

C

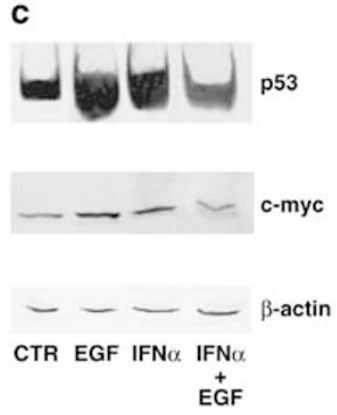

Figure 1 EGF antagonizes apoptosis induced by IFN $\alpha$ in human epidermoid cancer cells. KB cells were seeded and treated with IFN $\alpha$ and/or EGF as described in the Materials and methods section. (a) The internucleosomic DNA fragmentation was assessed as described in the Materials and methods section. (b) The percent of apoptotic cells, evaluated by FACS analysis, is shown as bars. CTR: untreated cells; IFN $\alpha$ : $48 \mathrm{~h} 1000 \mathrm{IU} / \mathrm{ml}$ IFN $\alpha$; EGF: $12 \mathrm{~h} 10 \mathrm{nM}$ EGF; IFN $\alpha+E G F: 48 \mathrm{~h} 1000 \mathrm{IU} / \mathrm{ml}$ IFN $\alpha+12 \mathrm{~h} 10 \mathrm{nM}$ EGF. The experiment was performed three times and S.E.s were always less than $5 \%$. (c) Evaluation of the expression of p53, c-myc and $\beta$-actin. Proteins were extracted and run on SDSPAGE as described in 'Materials and methods section'. The experiment was performed at least three times and the results were always similar. CTR: untreated cells; IFN $\alpha$ : $48 \mathrm{~h} 1000 \mathrm{IU} / \mathrm{ml}$ IFN $\alpha$; EGF: $12 \mathrm{~h} 10 \mathrm{nM}$ EGF; IFN $\alpha+E G F$ : $48 \mathrm{~h} 1000 \mathrm{IU} / \mathrm{ml}$ IFN $\alpha+12 \mathrm{~h} 10 \mathrm{nM}$ EGF; VP-16: $18 \mathrm{~h} 50 \mu \mathrm{M}$ etoposide

Raf-1, and we have found that Raf-1 activity is increased either by EGF or IFN $\alpha$ and is potentiated after EGF addition for $10 \mathrm{~min}$ to KB cells exposed to IFN $\alpha$ (Figure 4). Moreover, we have determined Raf-1 levels by Western blotting, and found that they were almost unmodified by the different treatments (Figure 4). These experiments demonstrate that an increase of basal and EGF-induced enzymatic activity of Raf-1 can be recorded downstream of the EGF->Ras signalling in IFN $\alpha$ treated cells.

\section{Effects of IFN $\alpha$ and EGF on Erk-1/2 activity}

On the basis of the finding that IFN $\alpha$ induced a hyperactivation of Mek-1, we have evaluated the effects of this cytokine on the activity of Erk-1/2, the downstream enzymatic targets of Raf1. We found that the exposure of KB cells to IFN $\alpha$ for short times $(5 \mathrm{~min}-12 \mathrm{~h})$ had no effects on MAPK activity, while they were maximally activated after $48 \mathrm{~h}$ of treatment with the cytokine (Figure 5a, lower panel). The latter effect paralleled EGF-R upregulation, which reached a peak after $48 \mathrm{~h}$ of exposure to IFN $\alpha$ (Figure 5a, upper panel and see also ref. 24). Therefore, the timing of $\mathrm{MAPK}^{25}$ activation by IFN $\alpha$ overlapped that of EGF-R upregulation, suggesting that the stimulation of MAPK activity could be a consequence of the increased surface expression of EGF-R with subsequent amplification of downstream signalling.

We have subsequently evaluated the kinetics of Erk-1/2 activation by EGF in untreated and IFN $\alpha$-treated KB cells. We again found an almost two-fold increase of the two enzyme activities in $48 \mathrm{~h} 1000 \mathrm{IU} / \mathrm{ml}$ IFN $\alpha$-treated cells. In both untreated and $48 \mathrm{~h} 1000 \mathrm{IU} / \mathrm{ml}$ IFN $\alpha$-treated KB cells, the maximal activation of Erk-1/2 occurred after $10 \mathrm{~min}$ of exposure to $10 \mathrm{nM}$ EGF, as evaluated with an immunoconjugated kinase assay (Figure $5 b$ and $c$ ). However, the exposure to IFN $\alpha$ caused an almost two-fold increase of the maximal activation of Erk-1/2 induced by EGF (Figure $5 b$ and $c$ ). Therefore, $48 \mathrm{~h}$ exposure to IFN $\alpha$ increased the activity of Erk$1 / 2$ without affecting the sensitivity to further stimulation by exogenous EGF.

\section{IFN $\alpha$ enhanced the apoptosis induced by dominant negative Ras plasmid RASN17 in KB cells}

We have shown that the EGF-dependent Ras-> Erk pathway was hyperactivated in cells exposed to IFN $\alpha$. In order to demonstrate that such signalling could indeed retain an antiapoptotic activity in the cells exposed to IFN $\alpha$, we have selectively inhibited Ras activity by a dominant negative mutant. KB cells have been cotransfected with a plasmid encoding for a dominant negative Ras RASN17 and with the E. coli $\beta$-galactosidase reporter gene. The cells were analyzed by FACS after PI labelling as described above. In all cases, the cotransfection resulted in specific green fluorescence in a fraction of the cell population owing to the expression of $\beta$ galactosidase (see Figure $6 \beta$ Gal NEG versus $\beta$ Gal POS). The latter effect allowed us the gating of nontransfected (G2) or transfected cells (G1) in order to perform cell cycle analysis (red fluorescence determined by PI labelling). We have found that $\beta$-galactosidase expression alone did not cause apoptosis (2 and $6 \%$ of apoptosis either in nontransfected or $\beta$ galactosidase-transfected cells, respectively) (Figure 6a, G2 
a

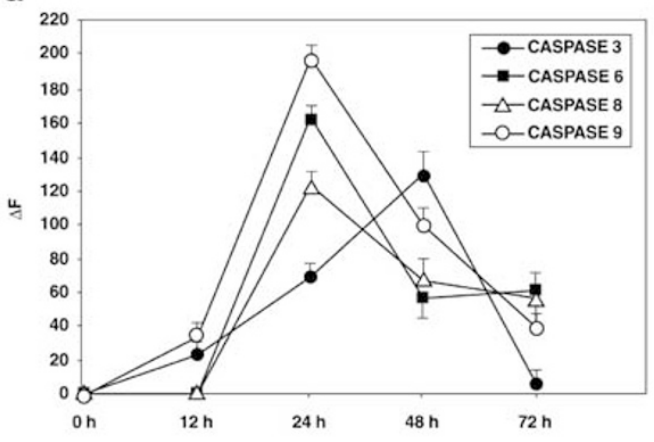

C

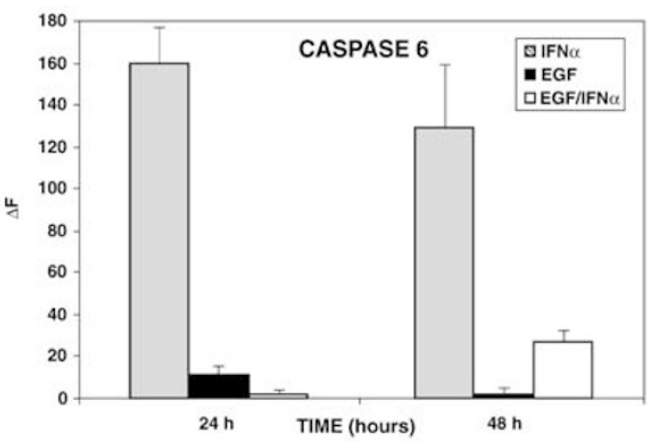

b

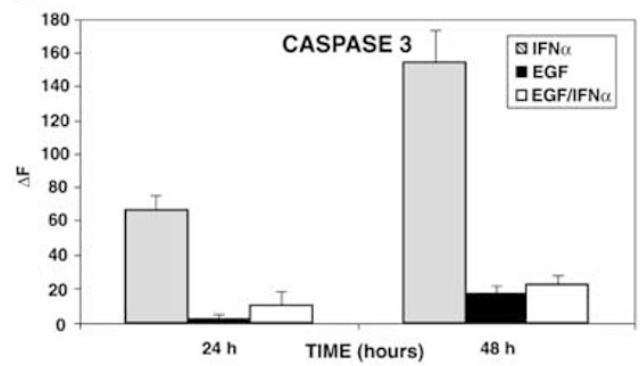

d

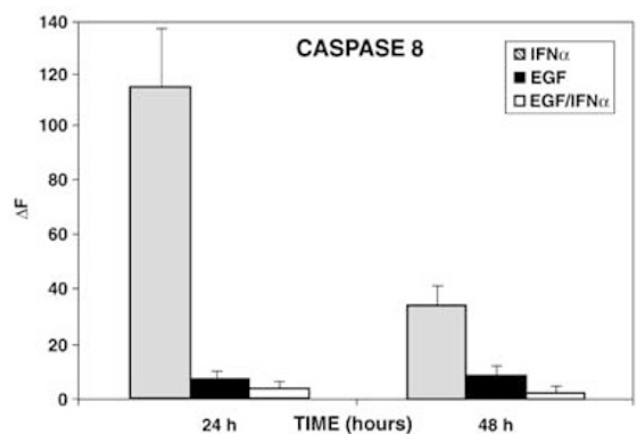

e

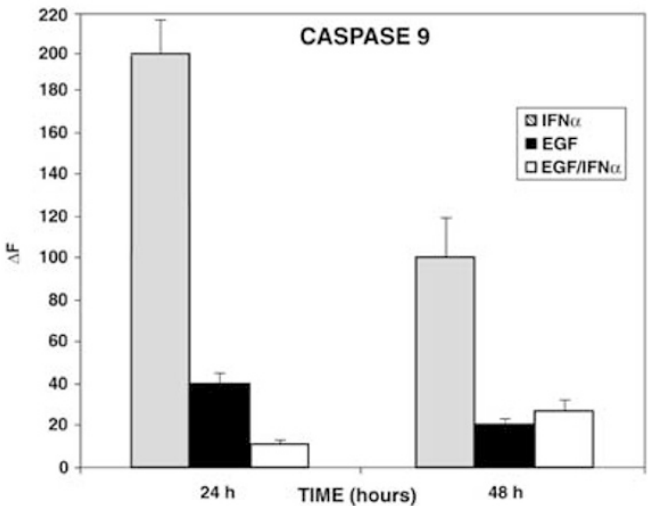

Figure 2 Modulation of caspases 3, 6, 8 and 9 by IFN $\alpha$ and EGF. (b) KB cells were seeded and treated with $1000 \mathrm{IU} / \mathrm{ml}$ IFN $\alpha$ for the indicated times. The specific caspase activity was determined with a fluorimetric assay as described in the 'Materials and methods section'. Caspase $3(\boldsymbol{O})$; caspase $6(\mathbf{\square})$; caspase 8 ( $\nabla)$; caspase 9 (O). The experiment was performed three times and S.D.s were always less than $5 \%$. Bars, s.d. (b-d) KB cells were seeded and treated with $1000 \mathrm{IU} / \mathrm{ml}$ IFN $\alpha$ for the indicated times. EGF $(10 \mathrm{nM})$ was added to the cells for the last $12 \mathrm{~h}$ of incubation alone or in combination with IFN $\alpha$. The specific caspase activity was determined with a fluorimetric assay as described in the 'Materials and Methods section'. Caspase 3 (b); caspase 6 (c); caspase 8 (d); caspase 9 (e). 1000 IU/ml IFN $\alpha$ (U/d ); 10 nM EGF (ם); IFN $\alpha+12 \mathrm{~h} 10 \mathrm{nM}$ EGF ( $\square$ ). The experiment was performed three times and S.D.s were always less than $5 \%$. Bars, S.D.

and G1). In the cells cotransfected with RASN17 and $\beta$ galactosidase almost $29 \%$ of apoptotic cells were detected (Figure $6 b, G 1$ ), while only $2 \%$ of apoptosis was found in nontransfected cells (Figure $6 \mathrm{~b}, \mathrm{G} 2$ ). The exposure of $\beta$ galactosidase-transfected cells to $1000 \mathrm{IU} / \mathrm{ml}$ IFN $\alpha$ for $24 \mathrm{~h}$ induced apoptosis in $16 \%$ of the cell population (Figure $6 \mathrm{c}$, G1) against $14 \%$ of apoptotic cells in nontransfected population (Figure 6c, G2). The treatment of $\beta$-galactosidase and RASN 17 cotransfected cells with $1000 \mathrm{IU} / \mathrm{ml}$ IFN $\alpha$ induced an almost $76 \%$ of apoptosis (Figure $6 \mathrm{D}, \mathrm{G} 1$ ), while programmed cell death was found in only $13 \%$ of the nontransfected cell population (Figure 6D, G2). We have performed these experiments after $24 \mathrm{~h}$ of exposure to IFN $\alpha$ because at this time maximal $\beta$-galactosidase expression occurred. Moreover, almost $80 \%$ of cells were apoptotic after $48 \mathrm{~h}$ from the transfection with RASN17 (data not shown). In this experiment about $30 \%$ of the cell population was transfected with $\beta$ galactosidase plasmid. It was therefore demonstrated that the abrogation of Ras activity by a transfected dominant negative mutant sensitized tumor cells to IFN $\alpha$-induced apoptosis, indicating an antiapoptotic function of Ras in this experimental model. 

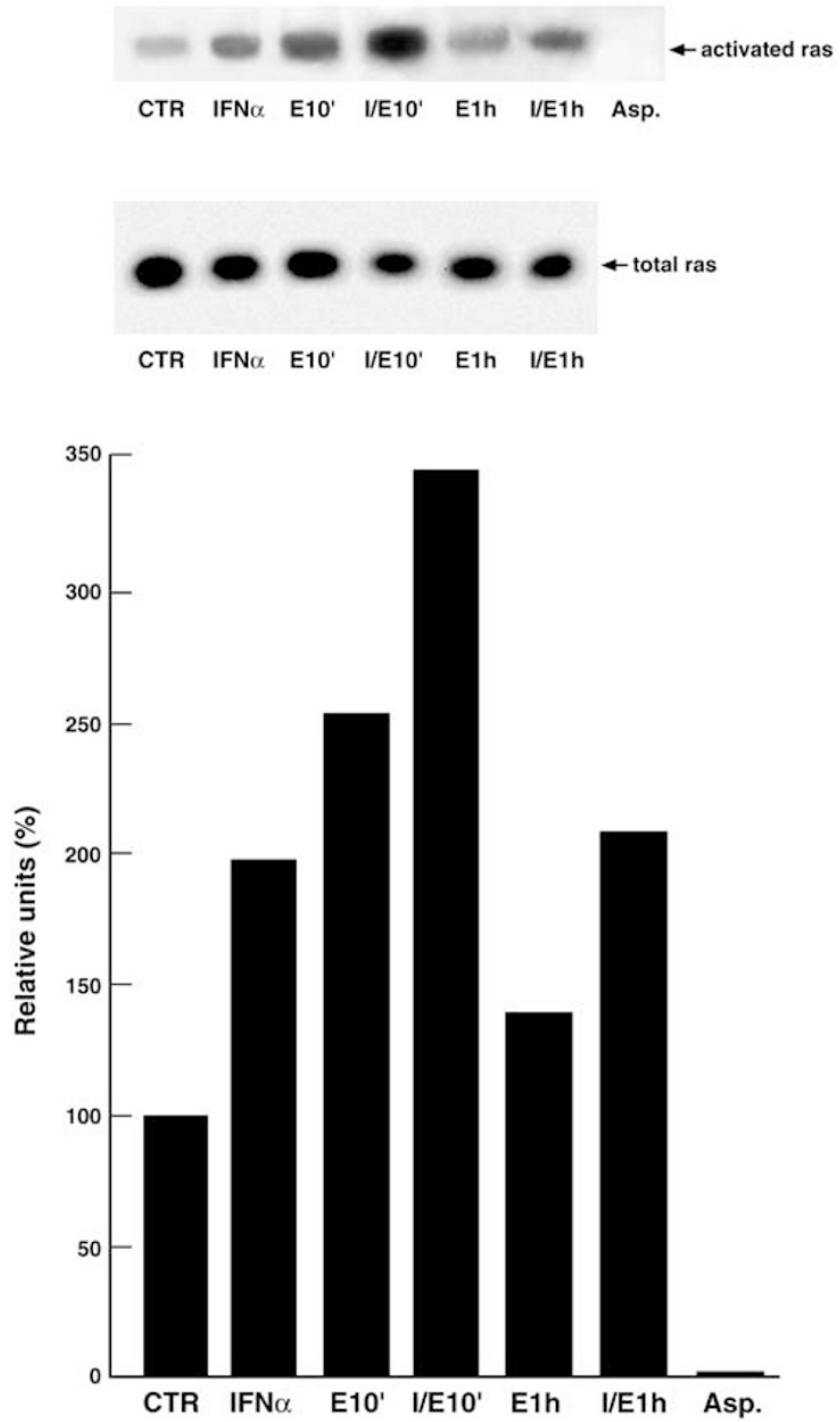

Figure 3 Effects of EGF and IFN $\alpha$ on Ras activity. (Upper gel) Affinity precipitation of Ras performed with the minimal binding domain of Raf- 1 conjugated with agarose as described in the 'Materials and methods section'. CTR, untreated; IFN $\alpha, 48 \mathrm{~h} 1000 \mathrm{IU} / \mathrm{ml}$ IFN $\alpha$; E10', $10 \mathrm{~min} 10 \mathrm{nM}$ EGF; I/E 10', $48 \mathrm{~h} 1000 \mathrm{IU} / \mathrm{ml} \mathrm{IFN} \alpha$ and $10 \mathrm{~min} 10 \mathrm{nM}$ EGF; E1 h, $1 \mathrm{~h} 10 \mathrm{nM} \mathrm{EGF} ; \mathrm{I} / \mathrm{E} 1 \mathrm{~h}, 48 \mathrm{~h}$ $1000 \mathrm{IU} / \mathrm{ml} \mathrm{IFN} \alpha$ and $1 \mathrm{~h} 10 \mathrm{nM}$ EGF; Asp, minimal binding domain of Raf-1 incubated only with Mab raised against Ras without cell extracts. (Lower gel) Western blot assay for the expression of the total Ras protein. CTR, untreated; IFN $\alpha, 48 \mathrm{~h} 1000 \mathrm{IU} / \mathrm{ml}$ IFN $\alpha$; E10', $10 \mathrm{~min} 10 \mathrm{nM} \mathrm{EGF;} \mathrm{I/E} \mathrm{10',} 48 \mathrm{~h} 1000 \mathrm{IU} / \mathrm{m}$ IFN $\alpha$ and $10 \mathrm{~min} 10 \mathrm{nM}$ EGF; E1 h, $1 \mathrm{~h} 10 \mathrm{nM} \mathrm{EGF;} \mathrm{//E} 1 \mathrm{~h}, 48 \mathrm{~h} 1000 \mathrm{IU} / \mathrm{ml} \mathrm{IFN} \alpha$ and $1 \mathrm{~h} 10 \mathrm{nM}$ EGF. The experiments were performed at least three different times and the results were always similar. (Bars) Quantitization of the intensity of the different bands with an appropriate apparatus (Bio-Rad) and expression as arbitrary units. CTR, untreated; IFN $\alpha, 48 \mathrm{~h} 1000 \mathrm{IU} / \mathrm{ml} \mathrm{IFN} \alpha$; E10', $10 \mathrm{~min} 10 \mathrm{nM}$ EGF; I/E 10', $48 \mathrm{~h} 1,000 \mathrm{IU} / \mathrm{ml}$ IFN $\alpha$ and $10 \mathrm{~min} 10 \mathrm{nM}$ EGF; E1 h, $1 \mathrm{~h} 10 \mathrm{nM}$ EGF; I/E $1 \mathrm{~h}, 48 \mathrm{~h} 1000 \mathrm{IU} / \mathrm{ml} \mathrm{IFN} \alpha$ and $1 \mathrm{~h} 10 \mathrm{nM}$ EGF; Asp, minimal binding domain of Raf-1 incubated only with Mab raised against Ras without cell extracts.

\section{MEK-1 inhibitor PD098059 specifically abrogated recovery from IFN $\alpha$-induced apoptosis by EGF}

Since Ras is implicated in the triggering of several different signal transduction pathways, we have verified that the integrity of the downstream ERK-targeted pathway was

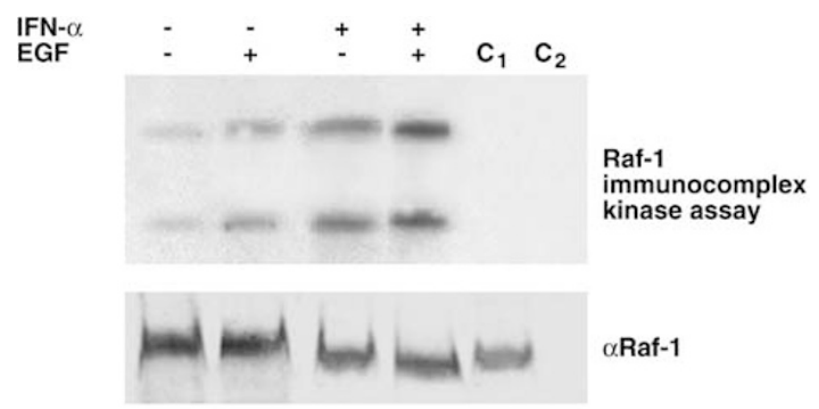

Figure 4 Effects of IFN $\alpha$ and EGF on Raf- 1 activity and expression. KB cells have been cultured for $48 \mathrm{~h}$ in the absence or presence of $1000 \mathrm{IU} / \mathrm{ml} \mathrm{IFN} \alpha$ with or without the addition of $10 \mathrm{nM}$ EGF for the last $5 \mathrm{~min}$ as described in the figure by + and - . Raf- 1 was immunoprecipitated and analyzed for kinase activity by immunocomplex kinase assay using histone $\mathrm{H} 1$ as substrate. Lane $\mathrm{C} 1$ indicated a control where the immunocomplex kinase assay was performed on untreated EGF-stimulated cells in the absence of the substrate. Lane C2 indicated a control assay performed using nonimmune serum to immunoprecipitate untreated EGFstimulated cells. At the same time, the cells were also processed for the determination of Raf- 1 expression as described in the 'Materials and Methods section'.

indeed required for the antiapoptotic effects of EGF. ${ }^{26}$ Therefore, we have evaluated if the specific inhibition of Mek-1 could also potentiate the growth inhibition and apoptosis induced by IFN $\alpha$ and if the Ras->Erk-1/2 pathway plays a crucial role in the survival of epidermoid cancer cells exposed to IFN $\alpha$. Only $5 \%$ untreated KB cells were apoptotic as assessed by FACS and in situ TUNEL analysis (Figure 7a). Again $48 \mathrm{~h} 1000 \mathrm{IU} / \mathrm{ml} \mathrm{IFN} \alpha$ induced $30 \%$ apoptosis and $12 \mathrm{~h}$ $10 \mathrm{nM}$ EGF antagonized this effect (only $8 \%$ apoptotic cells were recorded under these experimental conditions) (Figure $7 \mathrm{~b}$ and $\mathrm{e}$ and relative insets, respectively). In total, $50 \mu \mathrm{M}$ PD098059 and 10 nM EGF alone induced 35 and 15\% apoptosis, respectively (Figure $7 \mathrm{c}$ and $\mathrm{d}$, respectively). PD098059 was again able to enhance the effect induced by IFN $\alpha$ causing programmed cell death in about $80 \%$ of cells, thus suggesting a supra-additive effect induced by the addition of MEK-1 inhibitor to IFN $\alpha$ (Figure 7f). Moreover, $50 \mu \mathrm{M}$ PD098059 abrogated the anti-apoptotic effects of EGF in IFN $\alpha$-treated cells since an almost $30 \%$ of apoptosis was recorded in cells exposed to IFN $\alpha$, EGF and PD098059 (Figure 7h). On the other hand, PD098059 caused almost no effects on the apoptosis induced by EGF (Figure 7g). Interestingly, PD098059 reduced MAPK phosphorylation almost completely already after $6 \mathrm{~h}$ in KB cells (Figure 7i). All together, these data suggest that the antiapoptotic effects induced by EGF occurred through the activation of Erk, which is therefore the final target of an antiapoptotic kinase cascade.

\section{Discussion}

IFN $\alpha$ is a cytokine that has shown a well-defined but still limited activity against human tumors. ${ }^{1-5}$ Resistance to IFN $\alpha$ has been demonstrated to be in part based on receptor or post-receptor signalling defects in the tumor cells. ${ }^{6-8} \mathrm{How}$ ever, the cancer cell escape from the antiproliferative activity of IFN $\alpha$ and the mechanisms by which this cytokine causes 
a
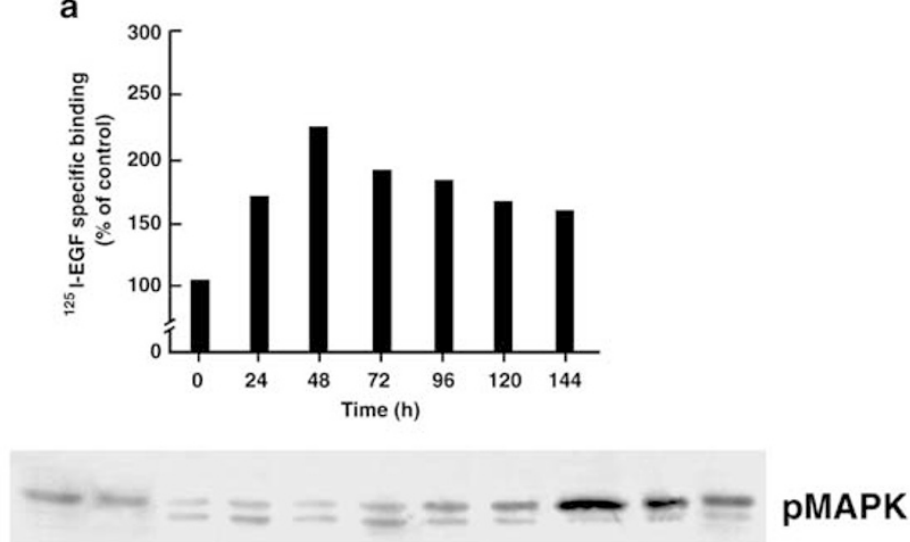

MAPK

IFN- $\alpha \quad 0 \quad 5^{\prime} \quad 10^{\prime} \quad 30^{\prime} \quad 1 \mathrm{~h} \quad 6 \mathrm{~h} \quad 12 \mathrm{~h} \quad 24 \mathrm{~h} \quad 48 \mathrm{~h} \quad 72 \mathrm{~h} 96 \mathrm{~h}$

b

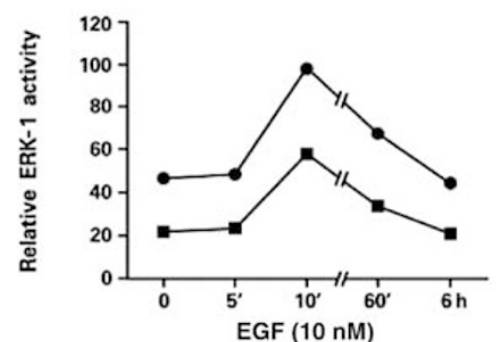

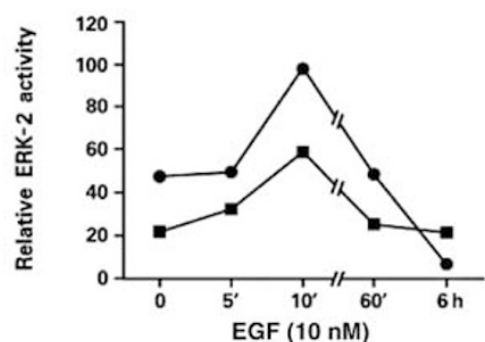

Figure 5 IFN $\alpha$ increases Erk-1 and Erk-2 activity in human epidermoid cancer cells. (A) upper panel) ${ }^{125}$ I-EGF binding on human epidermoid KB cells. KB cells were treated for different times with $1000 \mathrm{IU} / \mathrm{ml}$ IFN $\alpha$. At the indicated times, cells were processed for the determination of the ${ }^{125}$ |-EGF specific binding, as described in the 'Materials and methods section'. The values were expressed as \% of control. The experiments were performed three times and SDs were always less than $5 \%$. (a, lower panel) KB cells were cultured for the indicated times in the absence or presence of $1000 \mathrm{IU} / \mathrm{ml} \mathrm{INF} \alpha$. Then the cells were processed for the determination of the expression and phosphorylation of Erk-1 and -2 evaluated after blotting with an anti-MAPK and an anti-pMAPK specific Mab, respectively, as described in the 'Materials and methods section'. The experiments were performed at least three different times and the results were always similar. (b and c) KB cells were cultured for $48 \mathrm{~h}$ in the absence or presence of $1000 \mathrm{IU} / \mathrm{ml}$ IFN $\alpha$ with or without the addition of $10 \mathrm{nM} \mathrm{EGF}$ for different times. Then an immunoconjugated kinase assay of (b) Erk-1 and (c) Erk-2 was performed as described in 'Materials and Methods section'. Untreated KB cells ( $\mathbf{\square})$; IFN $\alpha$-treated KB cells $(\mathbf{O})$. The experiment was performed three times and s.d.s were always less than $5 \%$. Bars, s.d.

direct antitumor effect remain still unsolved. Apoptosis induction appears to be a way by which IFN $\alpha$ exerts its antiproliferative effects. $^{9-12}$ It is well established that tumor cells overcome the natural propensity to undergo apoptosis with the overexpression and/or overactivation of growth factor-induced signal transduction pathways. ${ }^{13-15}$ EGF-R overexpression is a common event in epidermoid cancers and is considered an unfavorable prognostic factor. ${ }^{27}$ It has also been demonstrated that Erk-1/2 antagonize apoptosis in several experimental models. ${ }^{22,28-30}$ We have previously reported that IFN $\alpha$ induces growth inhibition and increases the expression and function of EGF-R in human epidermoid cancer cells. ${ }^{23,24}$ Moreover, we have demonstrated that the growth inhibition induced by IFN $\alpha$ is, at least in part, because of the apoptosis triggered by a stress response leading to the activation of JNK-1, and that EGF antagonizes growth inhibition, apoptosis and the biochemical events induced by the cytokine. ${ }^{10}$ On the basis of these findings, we have hypothesized that the increased expression and function of the EGF-R could be part of a survival response that could protect tumor cells from the apoptosis triggered by IFN $\alpha$. In this paper, we have investigated the molecular bases of the counteracting effects of IFN $\alpha$ and EGF on apoptosis. We have firstly studied the involvement of caspases in the execution of the apoptotic process. We have found that IFN $\alpha$ induced an activation peak of caspases 6 and 8 after $24 \mathrm{~h}$, while the maximal activation of caspase 3 was recorded $24 \mathrm{~h}$ later. The differential timing of caspase activation is in agreement with the sequence of activation of these proteases during the apoptotic process and suggests an involvement of caspases in the execution of apoptosis induced by IFN $\alpha .{ }^{31}$ Our findings are, moreover, in agreement with the recent observations by Thyrell et al., ${ }^{32}$ who found induction of caspase activity by IFN $\alpha$ in apoptotic tumor cells. In our experimental conditions, we have found that the addition of EGF to IFN $\alpha$-treated KB cells completely antagonized apoptosis induction and the 
triggering of the caspase cascade, suggesting that the EGF-R signalling suppresses apoptosis, thereby antagonizing the activation of its executioners. These results appear also in line with the recent findings demonstrating the involvement of
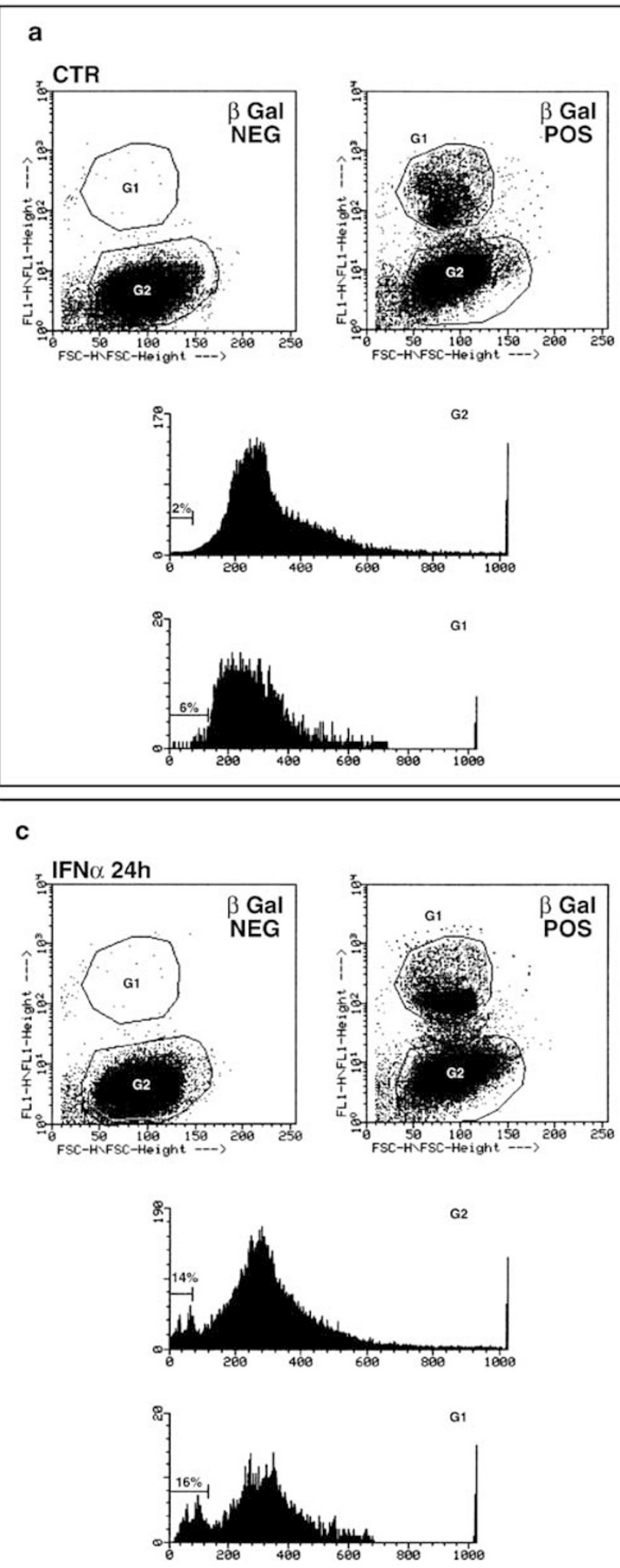

growth-factor-dependent pathways in the protection from caspase activation induced by Bad overexpression. Moreover, it has been demonstrated that the EGF-R-dependent pathway controls keratinocyte survival and the expression of b
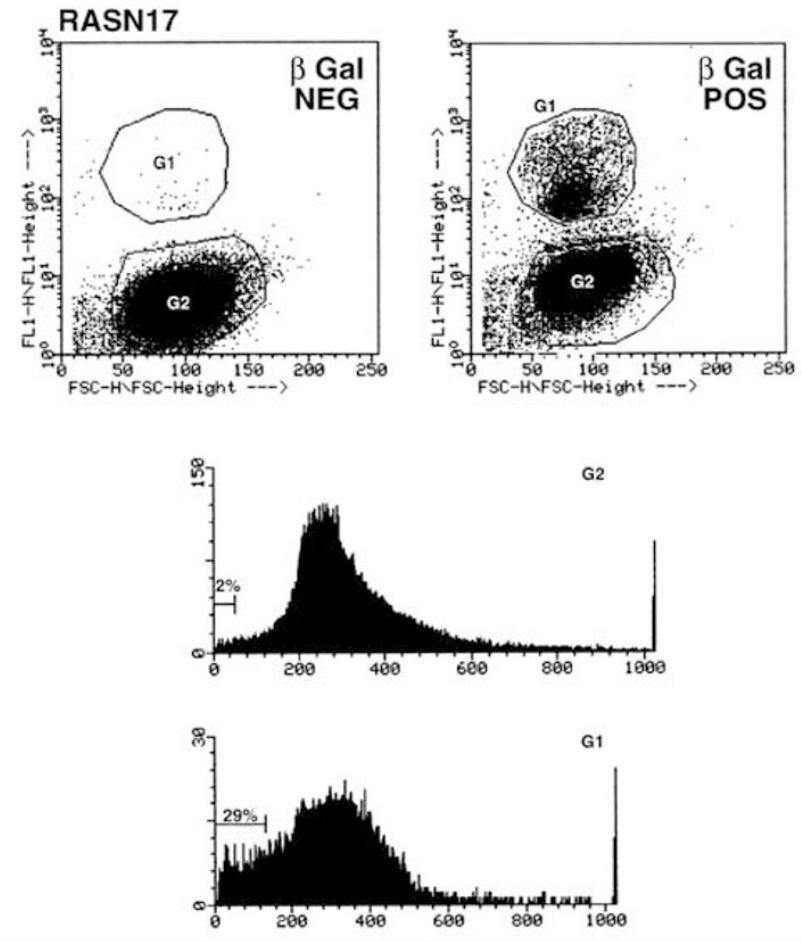

d
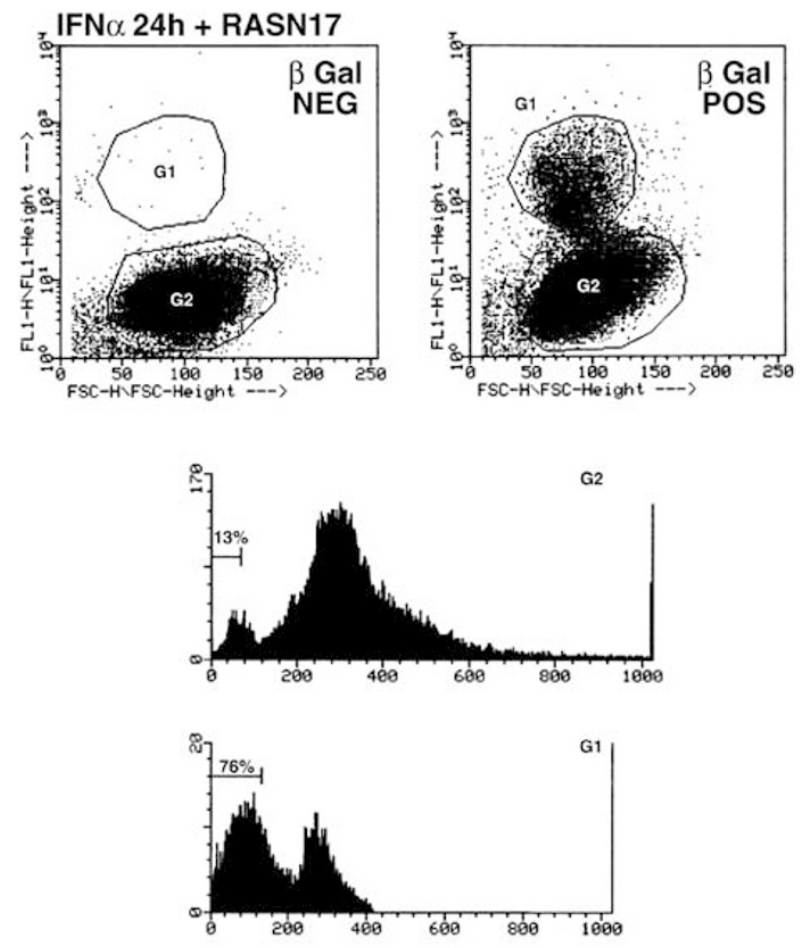
the proapoptotic bcl- $\mathrm{x}_{\mathrm{L}}$ expression through a Mek-dependent pathway. ${ }^{30}$

We have then investigated the involvement of EGFmediated intracellular signalling in the protection of epidermoid cancer cells from IFN $\alpha$-induced apoptosis. We have found that the EGF- and Ras-dependent MAPK cascade is hyperactivated in IFN $\alpha$-treated cells and could be further stimulated by the addition of EGF. In fact, we have demonstrated an increased activity and responsiveness to EGF stimulation of Ras, Raf-1 and Erk-1/2 in KB cells exposed to IFN $\alpha$. These findings suggest that the EGF-R function is preserved in IFN $\alpha$-treated cells, taking also into account the activation threshold of the EGF-dependent signalling. Interestingly, maximal MAPK hyperactivation occurred after $48 \mathrm{~h}$ from the beginning of the treatment with IFN $\alpha$. It must be considered that the maximal upregulation of EGF-R on the cell surface occurs with the same timing, suggesting that overstimulation of the MAPK pathway could be produced by the amplification of the EGF signalling owing to the increased expression of the receptor. ${ }^{23,24}$ We have previously described that other antiproliferative agents, such as cytosine arabinoside, 5aza-2' deoxycytidine and 8-chlorocAMP (8ClcAMP), also increase EGF-R expression on KB cells. ${ }^{33-35}$ On this basis, we have hypothesized that the upregulation of growth factor receptors is a common event in growth-inhibited tumor cells and could represent a protective response towards the antiproliferative stimuli. ${ }^{36}$ Also in the case of $8 \mathrm{ClcAMP}$, the EGF-induced signalling MAPK is amplified likely as a consequence of the increased expression of EGF-R. ${ }^{35}$ However, MAPK activity is reduced in $8 \mathrm{Cl}$-cAMPtreated KB cells, suggesting a selective inhibition of Erks or of a still unknown upstream activator induced by the drug. ${ }^{35}$ It has to be considered that chronic activation of Erk has been reported to induce apoptosis in eukaryotic cells. ${ }^{37-40}$ However, we can exclude that IFN $\alpha$-induced apoptosis occurs through the hyperactivation of Erks on the basis of both the timing of Erk activation and the effects of the combined treatment of KB cells with IFN $\alpha$ and EGF. In fact, we have found that the exposure of IFN $\alpha$-treated KB cells to EGF did not simply induce a recovery of cell growth, but it also caused a proliferative effect much greater than that recorded in $\mathrm{KB}$ cells exposed to EGF alone. ${ }^{24}$

The involvement of the Ras->MAPK pathway in the protection of KB cells from the apoptosis induced by IFN $\alpha$ is further demonstrated by both Ras inactivation by RASN17 transfection and Mek-1 inhibition by exposure to PD098059. In fact, the transfection of RASN17 in KB cells caused apoptosis as demonstrated by the FACS analysis performed on transfected cells and also potentiated the apoptosis induced by IFN $\alpha$. These data suggest that the integrity of Ras function was necessary to produce an anti-apoptotic signal that mediates a survival response in cells exposed to IFN $\alpha$ via Erk-1/2 activation. In fact, we have demonstrated that Ras-dependent survival signalling targets Erk-1/2 since the reduction of MAPK activity by PD098059 enhanced apoptosis caused by IFN $\alpha$. An additional important finding is that PD098059 specifically abrogated the recovery from apoptosis induced by EGF in IFN $\alpha$-treated cells. A second important antiapoptotic pathway involves signalling via Akt/PKB. ${ }^{41,42}$ In fact, it has been demonstrated that Akt can be activated concomitantly or independently from Ras->ERK-1/2 signalling by growth factors. ${ }^{43-45}$ Additionally, it has been reported that PC12 cells display a protective antiapoptotic pathway in response to hypoxic stimuli. ${ }^{46}$ The protection from apoptosis by Akt could be because of the regulation of mitochondrial physiology since Akt is involved in the regulation of bcl-related proteins such as $\mathrm{Mcl}-1 .{ }^{43}$ However, the requirement of Akt for the protection from apoptotic events is highly variable depending upon the experimental model used. ${ }^{44,45,47}$ In our experimental conditions, we have demonstrated that PD098059 completely antagonized the antiapoptotic effects of EGF. Moreover, we have preliminarily found that the specific EGF-R-associated kinase inhibitor ZD1839 (IRESSA) synergizes with IFN $\alpha$ in inducing the growth inhibition and apoptosis of several human epidermoid cancer cell lines, which is coupled to complete inhibition of ERK activity (A Budillon et al., manuscript in preparation). Therefore, our results suggest that the activation of Ras->Raf-1->Mek1$>$ Erk-1/2 signalling has a prominent role in the antiapoptotic effects exerted by EGF in epidermoid cancer cells exposed to IFN $\alpha$, providing evidence of the potential benefits of the molecular interference with this pathway. However, the occurrence of other survival pathways will warrant further investigations and we cannot presently completely exclude a role of the Akt pathway in the modulation of apoptosis of KB cells.

Consistent with our results, additional findings have been recently reported on the interaction between the Ras->Erk pathway and the myc oncogene on apoptosis onset. ${ }^{48}$ In fact, it has been recently found that the activation of the Ras/Mek signalling suppresses myc-dependent apoptosis in cells with MAPK cascade amplification because of Ras activation. ${ }^{48}$ In our experimental model, we have also found increased expression of p53 and c-myc in cells exposed to IFN $\alpha$ while the EGF anti-apoptotic effects were paralleled by downregulation of myc and p53 expression.

In conclusion, we have provided evidence that IFN $\alpha$ makes the survival of human epidermoid cancer cells dependent on

Figure 6 IFN $\alpha$ enhances the apoptosis induced by the dominant negative Ras plasmid RasN17 in KB cells. KB cells were seeded, electroporated with dominant negative Ras plasmid RASN17 and/or $\beta$-galactosidase plasmid, and treated with IFN $\alpha$ for $24 \mathrm{~h}$ as described above. Then the cells were fixed in methanol, incubated with anti- $\beta$-galactosidase MAb and anti-mouse FITC rabbit antiserum and analyzed after DNA labelling with propidium iodide. Cell cycle analysis was performed after appropriate gating on cell population expressing $\beta$-galactosidase as described in the 'Materials and methods section'. (a) Parental untreated cells (CTR); (b) RASN17 transfected cells (RASN17); (c) $24 \mathrm{~h} 1000 \mathrm{IU} / \mathrm{ml}$ IFN $\alpha$-treated parental cells (IFN $\alpha 24 \mathrm{~h}$ ); (D) $24 \mathrm{~h} 1000 \mathrm{IU} / \mathrm{ml}$ IFN $\alpha$-treated RasN17 transfected cells (IFN $\alpha$ $24 \mathrm{~h}+\mathrm{RASN} 17)$. $\beta$ Gal NEG, cells exposed to an irrelevant mouse IgG and subsequently labelled with an anti-mouse FITC rabbit antiserum. $\beta$ Gal POS, cells exposed to an anti- $\beta$-galactosidase mouse IgG and subsequently labelled with an anti-mouse FITC rabbit antiserum. G1, gating of cells expressing $\beta$-galactosidase; G2, gating of cells not expressing $\beta$-galactosidase. The lower histograms show the analysis of cell cycle performed on the G2 and G1 population, respectively. The apoptotic cells were shown as a percentage of total cell population indicated by a bar. The experiments were performed at least three different times and the results always gave less than $5 \%$ s.d. In each experimental point 10,000 events were analyzed. 

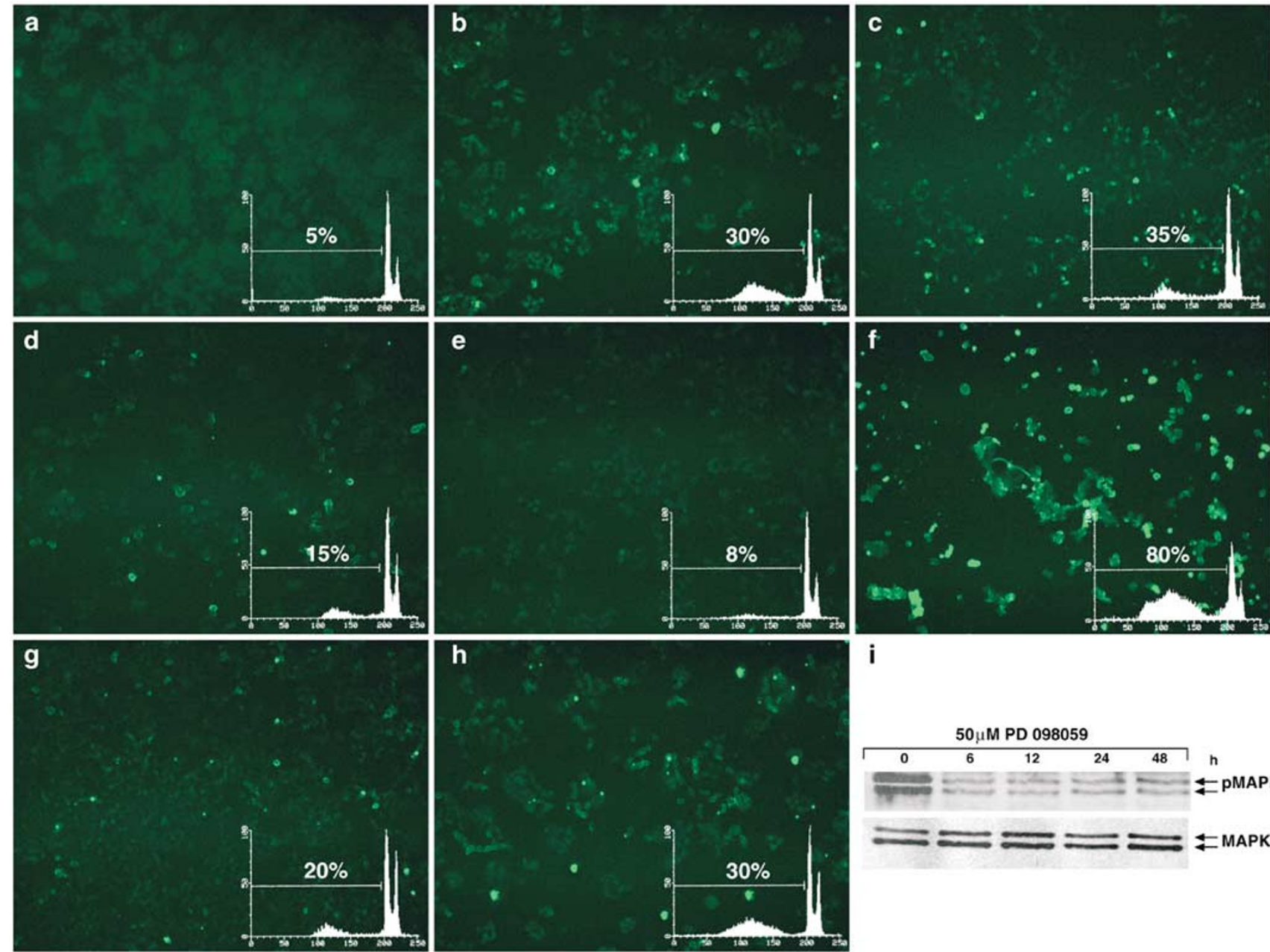

i

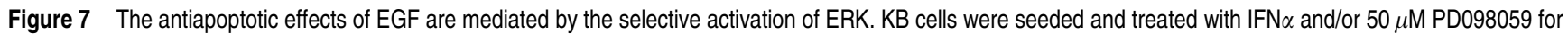
$48 \mathrm{~h}$ and/or $10 \mathrm{nM} \mathrm{EGF}$ for $12 \mathrm{~h}$. At the time of the experiment, cells were fixed and processed with TUNEL techniques as described in the 'Materials and methods section'. The experiments were performed at least three different times and the results were always similar. (a) Control cells; (b) $48 \mathrm{~h} 1000 \mathrm{IU} / \mathrm{ml}$ IFN $\alpha$-treated cells; (c) $48 \mathrm{~h} 50 \mu \mathrm{M}$ PD098059-treated cells; (d) $12 \mathrm{~h} 10 \mathrm{nM}$ EGF-treated cells; (e) $48 \mathrm{~h} 1000 \mathrm{IU} / \mathrm{ml} \mathrm{IFN} \alpha$ - and $12 \mathrm{~h} 10 \mathrm{nM}$ EGF-treated cells; (f) $48 \mathrm{~h} 1000 \mathrm{IU} / \mathrm{ml}$ IFN $\alpha$ - and $48 \mathrm{~h}$ $50 \mu \mathrm{M}$ PD098059 treated cells; (g) $12 \mathrm{~h} 10 \mathrm{nM}$ EGF- and $48 \mathrm{~h} 50 \mu \mathrm{M}$ PD098059-treated cells; (h) $48 \mathrm{~h} 1000 \mathrm{lU} / \mathrm{ml}$ IFN $\alpha$ - and $48 \mathrm{~h} 50 \mu \mathrm{M}$ PD098059-treated cells and $12 \mathrm{~h} 10 \mathrm{nM}$ EGF. Insets: The cells were seeded and treated with the different substances as described above. At the time of the experiment KB cells were FACS analyzed after detachment and DNA labelling with propidium iodide as described in the 'Materials and methods section'. The experiments were performed at least three different times and the results always gave less than 5\% SD. In each experimental point, 10,000 events were analyzed. (I) The expression and phosphorylation of Erk-1 and -2 was evaluated after blotting with an anti-p-MAPK (upper gel) and an anti-MAPK-specific MAb (lower gel) in KB cells treated for different times with $50 \mu \mathrm{M}$ PD098059. The experiments were performed at least three different times and the results were always similar

Ras/Erk signalling, which acts as a survival pathway. The specific disruption of the latter could be a useful approach to potentiate the antitumor activity of IFN $\alpha$ against human epidermoid tumors as indicated by the results achieved by selective interference with Ras and Mek-1 function in cells exposed to IFN $\alpha$.

\section{Materials and Methods}

\section{Materials}

DMEM, BSA and FBS were purchased from Flow Laboratories (Milan, Italy). Tissue culture plasticware was from Becton Dickinson (Lincoln Park, $\mathrm{NJ}$, USA). IFN $\alpha$ was a gift of Schering (Schering-Plough, NJ, USA).
Receptor grade EGF and protein Sepharose were purchased from Sigma (St. Louis, MO, USA). Rabbit antisera raised against Raf-1 C-12, Bactin, Erk-1 K-23 and Erk-2 MAb C-14 were purchased from Santa Cruz Biotechnology (Santa Cruz, CA, USA). Anti-pan-Ras MAb clone 10 was purchased from Calbiochem.

\section{Cell culture}

The human oropharyngeal epidermoid carcinoma KB cell line, obtained from the American Type Tissue Culture Collection, Rockville, MD, USA, was grown in DMEM supplemented with heat-inactivated $10 \% \mathrm{FBS}$, $20 \mathrm{mM} \mathrm{HEPES}, 100 \mathrm{U} / \mathrm{ml}$ penicillin, $100 \mu \mathrm{g} / \mathrm{ml}$ streptomycin, $1 \%$ Lglutamine and $1 \%$ sodium pyruvate. The cells were grown in a humidified atmosphere of $95 \%$ air $/ 5 \% \mathrm{CO}_{2}$ at $37^{\circ} \mathrm{C}$. 


\section{Western blot analysis}

$\mathrm{KB}$ cells were grown for $48 \mathrm{~h}$ with or without IFN $\alpha$ and were thereafter exposed for the indicated times to $10 \mathrm{nM} \mathrm{EGF}$ at $37^{\circ} \mathrm{C}$. For cell extract preparation, the cells were washed twice with ice-cold PBS/BSA, scraped, and centrifuged for $30 \mathrm{~min}$ at $4{ }^{\circ} \mathrm{C}$ in $1 \mathrm{ml}$ of lysis buffer (1\% Triton, $0.5 \%$ sodium deoxycholate, $0.1 \mathrm{NaCl}, 1 \mathrm{mM}$ EDTA, pH 7.5, $10 \mathrm{mM} \mathrm{Na2HPO4,}$ $\mathrm{pH} 7.4,10 \mathrm{mM}$ PMSF, $25 \mathrm{mM}$ benzamidin, $1 \mathrm{mM}$ leupeptin, $0.025 \mathrm{U} / \mathrm{ml}$ aprotinin). Equal amounts of cell proteins were separated by SDS-PAGE. The proteins on the gels were electrotransferred to nitrocellulose and reacted with the different MAbs.

\section{Affinity precipitation of Ras}

KB cells were treated with IFN $\alpha$ and EGF as described above. The cells were lysed in $\mathrm{Mg}^{2+}$ buffer containing $20 \mathrm{mM}$ HEPES, $\mathrm{pH} 7.5,150 \mathrm{mM}$ $\mathrm{NaCl}, 1 \%$ Igepal CA-630, $10 \mathrm{mM} \mathrm{MgCl}, 1 \mathrm{mM}$ EDTA and $2 \%$ glycerol. Then, $10 \mu$ l Ras binding domain (RBD) conjugated to agarose was added to $1 \mathrm{mg}$ of cell lysate and the mixture was incubated at $4{ }^{\circ} \mathrm{C}$ for $1 \mathrm{~h}$. The agarose beads were collected by microcentrifugation at $14,000 \times g$ for $5 \mathrm{~s}$. and washed three times with $\mathrm{Mg}^{2+}$ buffer. The agarose beads were boiled for 5 min in $2 \times$ Laemmli sample buffer and collected by a microcentrifuge pulse. The supernatants were run on $12 \%$ SDS-PAGE, then the proteins were electrotransferred on a nitrocellulose film. The nitrocellulose was incubated overnight with $1 \mu \mathrm{g} / \mathrm{ml}$ of anti-Ras Mab, clone RAS10 and with a secondary Mab, a goat $\alpha$-mouse HRP conjugated IgG, for $1.5 \mathrm{~h}$. The film was washed with PBS $/ 0.05 \%$ Tween 20 and detected by $E C L$, chemiluminescence's technique (Amersham).

\section{Internucleosomal DNA fragmentation (ladder)}

For all apoptosis evaluation experiments (gel ladder and FACS analysis), both attached and suspended cells were collected prior to the processing. DNA fragmentation was measured after extraction of low molecular weight DNA. Briefly, $10 \times 10^{6}$ cells were resuspended in $900 \mu \mathrm{l} 1 \times$ Tris-EDTA buffer and lysed with $25 \mu \mathrm{l} 20 \%$ SDS. DNA was precipitated in ethanol for $6 \mathrm{~h}$ in the presence of $5 \mathrm{M} \mathrm{NaCl}$. The high molecular weight fraction was sedimented by high-speed centrifugation, and the fragmented DNA was extracted from the aqueous phase with phenol and chloroform and then precipitated with ethanol. After resuspension in water, DNA was electrophoresed using 1.5\% agarose gel and visualized by ultraviolet light following ethidium bromide staining.

\section{Evaluation of apoptosis by DNA-flow cytometry}

Cells were centrifuged and directly stained in a propidium iodide (PI) solution ( $50 \mu \mathrm{g} \mathrm{Pl}$ in $0.1 \%$ sodium citrate, $0.1 \% \mathrm{NP} 40, \mathrm{pH} 7.4$ ) overnight at $4{ }^{\circ} \mathrm{C}$ in the dark. Flow cytometric analysis was performed using a FACScan flow cytometer (Becton Dickinson, San Jose, CA, USA) interfaced with a Hewlett-Packard computer (mod. 310) for data analysis. To evaluate cell apoptosis, PI fluorescence was collected as FL2 (log scale) by the CellFIT software (Becton Dickinson). For the evaluation of apoptosis after transfection with RASN17 and/or $\beta$-galactosidase plasmids, cells were fixed in methanol and then incubated with an anti- $\beta$-galactosidase MAb for $1 \mathrm{~h}$ at $4{ }^{\circ} \mathrm{C}$ and labelled with an FITC anti-mouse rabbit antibody for $1 \mathrm{~h}$. Thereafter, the cells were stained with PI as described above. In the latter case, apoptosis and cell cycle analysis were performed on the whole cell population and on $\beta$-galactosidase expressing cells after appropriate gating. For the evaluation of intracellular DNA content, at least 10,000 events for each point were analyzed in at least three different experiments giving a s.d. less than $5 \%$.

\section{MAPK assay}

$\mathrm{KB}$ cells were cultured and treated as described above. Then the cells were washed twice with ice-cold PBS, scraped and lysed for $1 \mathrm{~h}$ at $4{ }^{\circ} \mathrm{C}$ in the following buffer: $10 \mathrm{mM}$ TRIS, $150 \mathrm{mM} \mathrm{NaCl}, 2 \mathrm{mM}$ EGTA, $2 \mathrm{mM}$ DTT, $1 \mathrm{mM}$ sodium orthovanadate, $1 \mathrm{mM}$ PMSF, $10 \mu \mathrm{g} / \mathrm{ml}$ aprotinin, $10 \mu \mathrm{g} / \mathrm{ml}$ leupeptin and $1 \%$ glycerol. Equalized amounts of proteins from lysates of $\mathrm{KB}$ cells $(50 \mu \mathrm{l})$ were incubated for $90 \mathrm{~min}$ at $4^{\circ} \mathrm{C}$ with $50 \mu \mathrm{l}$ of protein ASepharose conjugated to $25 \mu \mathrm{g}$ anti-Erk-1 or anti-Erk-2 MAbs. The suspension was centrifuged at $14,000 \times g$, the supernatant discarded, and the immunoprecipitated washed twice with $250 \mu$ lo the following buffer: $20 \mathrm{mM}$ Tris-acetate, $\mathrm{pH} 7.0\left(20^{\circ} \mathrm{C}\right), 0.27 \mathrm{M}$ sucrose, $1 \mathrm{mM}$ EDTA, $1 \mathrm{mM}$ EGTA, $1 \mathrm{mM}$ sodium orthovanadate, $10 \mathrm{mM}$ sodium glycerophosphate, $50 \mathrm{mM}$ sodium fluoride, $5 \mathrm{mM}$ sodium pyrophosphate, $1 \%$ Triton $\mathrm{X}-100,0.1 \%$ 2-mercaptoethanol, $1 \mathrm{mM}$ benzamidine, $0.2 \mathrm{mM}$ phenylmethylsulfonylfluoride and $0.5 \mathrm{M} \mathrm{NaCl}$. The immunoprecipitates were washed once with $250 \mu \mathrm{l}$ of the following buffer: $50 \mathrm{mM}$ Tris- $\mathrm{HCl}$, pH 7.5 $\left(20^{\circ} \mathrm{C}\right), 0.03 \%$ Brij-35, $0.1 \mathrm{mM}$ EGTA and 0.1\% 2-mercaptoethanol. Then the immunoprecipitates were incubated for $30 \mathrm{~min}$ at $30^{\circ} \mathrm{C}$ with $5 \mu \mathrm{l}$ of a solution containing $1.2 \mathrm{mM} \mathrm{Mg}^{++}$ATP with $200 \mu \mathrm{Ci} / \mathrm{ml}$ of $\left[\gamma^{32} \mathrm{P}\right]$ ATP and $15 \mu \mathrm{l}$ of a solution containing a peptide that is specifically phosphorylated by MAPK (Amersham, Biotrak, Milan, Italy). ${ }^{25}$ The reaction was stopped with the addition of $2.94 \%$ (w/v) ortophosphoric acid and red carmosin solution and then microfuged for $15 \mathrm{~s}$. The reaction mixtures were spotted onto phosphocellulose filters (Whatman P81) and washed three times in $1 \%$ acetic acid. Filters were air-dried and then counted by liquid scintillation using Omnifluor/toluene (DuPont-New England Nuclear, Boston, MA, USA).

\section{Raf-1 kinase assay}

Assay for Raf-1 kinase activity was performed by immunocomplex kinase assay as already described for MAPK using anti-Raf-1 antiserum. $\mathrm{H} 1$ histone $(10 \mu \mathrm{g})$ (Upstate Biotechnology Inc.) was used as substrate in $30 \mu \mathrm{l}$ of buffer A containing $10 \mu \mathrm{Ci}$ of $\left[\gamma^{32} \mathrm{P}\right] \mathrm{ATP}$, the reaction was allowed to proceed for $30 \mathrm{~min}$ at $30^{\circ} \mathrm{C}$, and the proteins were separated by SDS$12.5 \%$ PAGE.

\section{Electroporation}

Cells were detached from confluent $100 \mathrm{~mm}$ - dishes. Cells $\left(100 \times 10^{6}\right)$ were incubated in appropriate electroporation vials with $800 \mu \mathrm{l}$ of electroporation buffer $(20 \mathrm{mM}$ HEPES, $137 \mathrm{mM} \mathrm{NaCl}, 5 \mathrm{mM} \mathrm{KCl}$, $0.7 \mathrm{mM} \mathrm{Na}_{2} \mathrm{HPO}_{4}$ and $6 \mathrm{mM}$ glucose) and $15 \mu \mathrm{g}$ of the RASN17 DNA and $/$ or $5 \mu \mathrm{g} / \mathrm{ml} \beta$-galactosidase DNA in $20 \mathrm{mM}$ HEPES. Then cells were electroporated at $250 \mathrm{~V}$ and at $975 \mu \mathrm{F}$ for $6 \mathrm{~s}$. The cells were incubated at $37^{\circ} \mathrm{C}$ with or without $1000 \mathrm{IU} / \mathrm{ml} \mathrm{IFN} \alpha$ for $24 \mathrm{~h}$. After the incubation, the cells were processed for FACS analysis as described above.

\section{TUNEL technique}

For TUNEL assay, after washing in PBS supplemented in $0.1 \%$ BSA, cells were treated with an in situ detection kit, according to the manufacturers instructions (Boehringer Mannheim Biochemicals). Nuclei with fragmented DNA were visualized by a fluorescence microscope. 


\section{Determination of caspase activity}

Cells were seeded and treated with $1000 \mathrm{IU} / \mathrm{ml} \mathrm{IFN} \alpha$ for different times and/or $10 \mathrm{nM}$ EGF for $12 \mathrm{~h}$. At the time of caspase determination, cells were lysed. For each reaction, $50 \mu \mathrm{l}$ of cell lysate was added to $1 \mathrm{ml}$ reaction mixture composed of reaction buffer, DTT $10 \mathrm{mM}$ and the specific substrate peptide (DEVD for caspase-3, VEID for caspase-6, IETD for caspase-8 and LEHD for caspase-9) conjugated to 7-amino-4-trifluoromethylcoumarin (AFC). The mixtures were incubated for $1 \mathrm{~h}$ at $37^{\circ} \mathrm{C}$. The levels of free AFC were measured using a spectrofluorometer with an excitation wavelength of $400 \mathrm{~nm}$ and an emission wavelength range of $480-520 \mathrm{~nm}$ (peak at $505 \mathrm{~nm}$ ).

\section{Acknowledgments}

We thank Prof. N Perrotti and G Cuda of Catanzaro University for the careful reading of the paper and Ms. G Granata and Dr. P Sands for their help in the manuscript preparation. This work was partially supported by the Italian Association for Cancer Research (AIRC) and by grants from the Italian Ministry for Research (PRIN2001) and the Italian Ministry of Health (FSN99 and FSN2000).

\section{References}

1. Agarwala SS and Kirkwood JM (1998) Adjuvant therapy of melanoma. Semin. Surg. Oncol. 14: 302-310

2. Vlock DR Andersen J Kalish LA Johnson JT Kirkwood JM Whiteside T Herberman RB Adams GS Oken MM and Haselow RE (1996) Phase II trial of interferon-alpha in locally recurrent or metastatic squamous cell carcinoma of the head and neck: immunological and clinical correlates. J. Immunother. Emphasis Tumor Immunol. 19: 433-442

3. Kirkwood JM, Resnick GD and Cole BF (1997) Efficacy, safety, and risk-benefit analysis of adjuvant interferon alfa-2b in melanoma. Semin. Oncol. 24: 16-23

4. Kirkwood JM Strawderman MH Ernstoff MS Smith TJ Borden EC and Blum RH (1996) Interferon alfa-2b adjuvant therapy of high-risk resected cutaneous melanoma: the Eastern Cooperative Oncology Group Trial EST 1684. J. Clin. Oncol. 14: 7-17

5. Gutterman JU (1994) Cytokine therapeutics: lessons from interferon alpha. Proc. Natl. Acad. Sci. USA 91: 1198-1205

6. Wong LH Kraver KG Hatzinisiriou I Estcourt M J Hersey P Tam ND Edmondson S Devenish RJ and Ralph SJ (1997) Interferon-resistant human melanoma cells are deficient in ISGF3 components, STAT1, STAT2, and p48ISGF3gamma. J. Biol. Chem. 272: 28779-28785

7. Ransohoff RM. (1998) Cellular responses to interferons and other cytokines: the JAK-STAT paradigm. N. Engl. J. Med. 338: 616-618

8. Harvat BL Jetten AM and Seth P (1997) The role of p27Kip1 in gamma interferon-mediated growth arrest of mammary epithelial cells and related defects in mammary carcinoma cells. Oncogene, 14: 2111-2122

9. Rodriguez-Villanueva J and McDonnell TJ (1995) Induction of apoptotic cell death in non-melanoma skin cancer by interferon-alpha. Int. J. Cancer 61: 110114

10. Caraglia M Abbruzzese A Leardi A Pepe S Budillon A Baldassarre G Selleri C De Lorenzo S Fabbrocini A Giuberti G Vitale G Lupoli G Bianco AR and Tagliaferri $P$ (1999) Interferon-alpha induces apoptosis in human KB cells through a stress-dependent mitogen activated protein kinase pathway that is antagonized by epidermal growth factor. Cell Death Differ. 6: 773-780

11. Roth W Wagenknecht B Dichgans J and Weller MJ (1998) Interferon-alpha enhances CD95L-induced apoptosis of human malignant glioma cells. J. Neuroimmunol. 87: 121-129

12. Tanaka N Sato M Lamphier MS Nozawa H Oda E Noguchi S Schreiber RD Tsujimoto $Y$ and Taniguchi T (1998) Type I interferons are essential mediators of apoptotic death in virally infected cells. Genes Cells 3: 29-37

13. Tilly JL Billig H Kowalski KI and Hsueh AJ (1992) Epidermal growth factor and basic fibroblast growth factor suppress the spontaneous onset of apoptosis in cultured rat ovarian granulosa cells and follicles by a tyrosine kinase-dependent mechanism. Mol. Endocrinol. 6: 1942-1950

14. Peng H Wen TC Tanaka J Maeda N Matsuda S Desaki J Sudo S Zhang B and Sakanaka M (1998) Epidermal growth factor protects neuronal cells in vivo and in vitro against transient forebrain ischemia- and free radical-induced injuries. J. Cereb. Blood Flow Metab. 18: 349-360

15. Stoll SW Benedict M Mitra R Hiniker A Elder JT and Nunez G (1998) EGF receptor signalling inhibits keratinocyte apoptosis: evidence for mediation by Bcl-XL. Oncogene 16: 1493-1499

16. Sibilia M Fleischmann A Behrens A Stingl L Carroll J Watt FM Schlessinger J and Wagner EF (2000) The EGF receptor provides an essential survival signal for SOS-dependent skin tumor development. Cell, 102: 211-220

17. Widmann C Gibson S Jarpe MB and Johnson GL (1999) Mitogen-activated protein kinase: conservation of a three-kinase module from yeast to human. Physiol. Rev. 79: 143-180

18. Garrington TP and Johnson GL (1999) Organization and regulation of mitogen-activated protein kinase signaling pathways. Curr. Opin. Cell Biol. 11: $211-218$

19. Xia Z Dickens M Raingeaud J Davis RJ and Greenberg ME (1995) Opposing effects of ERK and JNK-p38 MAP kinases on apoptosis. Science 270: 13261331

20. Yan CYI and Greene LA (1998) Prevention of PC12 cell death by $\mathrm{N}$ acetylcysteine requires activation of the Ras pathway. J. Neurosci. 18: 40424049

21. Aikawa R Komuro I Yamazaki T Zou Y Kudoh S Tanaka M Shiojima I Hiroi Y and Yazaki Y (1997) Oxidative stress activates extracellular signal-regulated kinases through Src and Ras in cultured cardiac myocytes of neonatal rats. J. Clin. Invest. 100: 1813-1821

22. Stadheim TA and Kucera GL (1998) Extracellular signal-regulated kinase (ERK) activity is required for TPA-mediated inhibition of drug-induced apoptosis. Biochem. Biophys. Res. Commun. 245: 266-271

23. Budillon A Tagliaferri P Caraglia M Torrisi MR Normanno N lacobelli S Palmieri G Stoppelli MP Frati L and Bianco AR (1991) Upregulation of epidermal growth factor receptor induced by alpha-interferon in human epidermoid cancer cells. Cancer Res., 51: 1294-1299

24. Caraglia M Leardi A Corradino S Ciardiello F Budillon A GuarRasi R Bianco AR and Tagliaferri $P$ (1995) alpha-Interferon potentiates epidermal growth factor receptor-mediated effects on human epidermoid carcinoma KB cells. Int. J. Cancer 61: 342-347

25. Clark-Lewis I Sanghera JS and Pelech SL (1991) Definition of a consensus sequence for peptide substrate recognition by $\mathrm{p} 44 \mathrm{mpk}$, the meiosis-activated myelin basic protein kinase. J. Biol. Chem. 266: 15180-15184

26. Shields JM Pruitt K Mc Fall A Shaub A and Der CJ (2000) Understanding Ras: it ain't over til it's over'. Trends Cell. Biol. 10: 147-154

27. Gullick WJ Marsden JJ and Whittle N (1986) Expression of epidermal growth factor receptors on human cervical, ovarian, and vulval carcinomas. Cancer Res. 46: 285-292

28. Foncea R Galvez A Perez V Morales MP Calixto A Melendez J Gonzalez-Jara F Diaz-Araya G Sapag-Hagar M Sugden PH LeRoith D and Lavandero S (2000) Extracellular regulated kinase, but not protein kinase $C$, is an antiapoptotic signal of insulin-like growth factor-1 on cultured cardiac myocytes. Biochem. Biophys. Res. Commun. 273: 736-744

29. Kang C Yoo S Hwang B Kim K Kim D Kim C Kim S and Chung B (2000) The inhibition of ERK/MAPK not the activation of JNK/SAPK is primarily required to induce apoptosis in chronic myelogenous leukemic K562 cells. Leuk. Res. 24: 527-534

30. Jan MS Liu HS and Lin YS (1999) Bad overexpression sensitizes NIH/3T3 cells to undergo apoptosis which involves caspase activation and ERK inactivation. Biochem. Biophys. Res. Commun. 264: 724-729

31. Nunez G Benedict MA Hu Y and Inohara N (1998) Caspases: the proteases of the apoptotic pathway. Oncogene 17: 3237-3245

32. Thyrell L Erickson S Zhivotovsky B Pokrovskaja K Sangfelt O Castro J Einhorn $S$ and Grander D (2002) Mechanisms of interferon-alpha induced apoptosis in malignant cells. Oncogene 21: 1251-1262

33. Caraglia M Tagliaferri P Correale P Genua G Pepe S Pinto A Del Vecchio S Esposito $G$ and Bianco AR (1993) Cytosine arabinoside increases the binding of 125l-labelled epidermal growth factor and 125I-transferrin and enhances the in vitro targeting of human tumor cells with anti-(growth factor receptor) $\mathrm{mAb}$. Cancer Immunol. Immunother. 37: 150-156 
34. Caraglia M Pinto A Correale P Zagonel V Genua G Leardi A Pepe S Bianco AR and Tagliaferri $P$ (1994) 5-Aza-2'-deoxycytidine induces growth inhibition and upregulation of epidermal growth factor receptor on human epithelial cancer cells. Ann. Oncol. 5: 269-276

35. Budillon A Di Gennaro E Caraglia M Barbarulo D Abbruzzese A and Tagliaferri P (1999) 8-Cl-cAMP antagonizes mitogen-activated protein kinase activation and cell growth stimulation induced by epidermal growth factor. Br. J. Cancer 81: $1134-1141$

36. Tagliaferri $P$ Caraglia $M$ Muraro $R$ Budillon A Pinto A and Bianco AR (1994) Pharmacological modulation of peptide growth factor receptor expression on tumor cells as a basis for cancer therapy. Anti-Cancer Drugs 5: 379-393

37. Zimmermann S Moelling K (1999) Phosphorylation and regulation of Raf by Akt (protein kinase B). Science 286: 1741-1744

38. Kauffmann Zeh A Rodriguez-Viciana P Ulrich E Gilbert C Coffer P Downward J and Evan G (1997) Suppression of c-Myc-induced apoptosis by Ras signalling through PI(3)K and PKB. Nature 385: 544-548

39. Serrano M Lin AW Mc Currach ME Beach D and Lowe SW (1997) Oncogenic Ras provokes premature cell senescence associated with accumulation of $p 53$ and p16INK4a. Cell 88: 593-602

40. Arase $\mathrm{Y}$ Hiwasa T Hasegawa R Nomura J Ito $\mathrm{H}$ and Suzuki N (2000) Prevention of $\mathrm{v}$-Ha-Ras-dependent apoptosis by PDGF coordinates in phosphorylation of ERK and Akt. Biochem. Biophys. Res. Commun. 267: 33-39

41. von Gise A Lorenz P Wellbrock C Hemmings B Berberich-Siebelt F Rapp UR and Troppmair J (2001) Apoptosis suppression by Raf-1 and MEK1 requires
MEK- and phosphatidylinositol 3-kinase-dependent signals. Mol. Cell. Biol. 21: 2324-2336

42. Zhou H Li X-M Meinkoth J and Pittman RN (2000) Akt regulates cell survival and apoptosis at a postmitochondrial level. J. Cell Biol. 151: 483-494

43. Kuo ML Chuang SE Lin MT and Yang SY (2001) The involvement of PI 3-K/Aktdependent up-regulation of $\mathrm{MCl}-1$ in the prevention of apoptosis of Hep3B cells by interleukin-6. Oncogene 20: 677-685

44. Liu B Fang M Lu Y Mendelsohn J and Fan Z (2001) Fibroblast growth factor and insulin-like growth factor differentially modulate the apoptosis and G1 arrest induced by anti-epidermal growth factor receptor monoclonal antibody. Oncogene 20: 1913-1922

45. Mitsui $\mathrm{H}$ Takuwa $\mathrm{N}$ Maruyama $\mathrm{T}$ Maekawa $\mathrm{H}$ Hirayama M Sawatari $\mathrm{T}$ Hashimoto N Takuwa $Y$ and Kimura $S$ (2001) The MEK1-ERK map kinase pathway and the PI 3-kinase-Akt pathway independently mediate anti-apoptotic signals in HepG2 liver cancer cells. Int. J. Cancer 92: 55-62

46. Alvarez-Tejado M Naranjo-Suarez S Jimenez C Carrera AC Landazuri MO and del Peso L (2001) Hypoxia induces the activation of the phosphatidylinositol 3kinase/Akt cell survival pathway in PC12 cells: protective role in apoptosis. J. Biol. Chem. 22: 22368-22374

47. Chaudhary LR and Hruska KA (2001) The cell survival signal Akt is differentially activated by PDGF-BB, EGF, and FGF-2 in osteoblastic cells. J. Cell Biochem. 81: $304-311$

48. Tsuneoka M and Mekada E (2000) Ras/MEK signalling suppresses Mycdependent apoptosis in cells transformed by c-myc and activated Ras. Oncogene, 19: 115-123 